\title{
The effect of vegetation harvest on the operation of a surface flow constructed wetland
}

\author{
JA Álvarez ${ }^{*}$ and E Bécares ${ }^{2}$ \\ ${ }^{1}$ Environmental Institute, University of León, La Serna, 56, 24007, León, Spain \\ ${ }^{2}$ Department of Genetic Ecology and Microbiology, University of León, Campus de La Vegazana, 24071, León, Spain
}

\begin{abstract}
Constructed wetlands represent a low-cost and highly efficient municipal wastewater treatment alternative, due to their low technological and energy demands. Wetland vegetation releases an amount of carbon to the system, when it is decomposed (winter period). Part of this organic matter could remain in the system, and will be decomposed at very low rates during winter and spring. In this research, a constructed superficial-flow wetland was divided into two equal parts and vegetation (Typha latifolia) was harvested in one of them. The organic load applied to the system was $11.2 \mathrm{gBOD} / \mathrm{m}^{2} \cdot \mathrm{d}$. The control of the organic matter was carried out during $141 \mathrm{~d}$ (111 d in winter and $30 \mathrm{~d}$ in spring). Differences in efficiencies (TSS, BOD and COD), were observed between both types of the wetland, with an important increase in these differences during spring. Vegetation released organic matter to the system, specially suspended and biodegradable matter. BOD and TSS released per dry gram of Typha were $4.24 \mathrm{mgBOD} / \mathrm{g} T y p h a$ and $4.36 \mathrm{mgTSS} / \mathrm{g} T y p h a$, respectively. Harvest is a recommended practice in systems treating diluted wastewater, especially in productive areas like the Mediterranean. The recommendations can also be applied to a broader geographic area.
\end{abstract}

Keywords: wastewater treatment wetlands, Typha, decomposition, biodegradable organic matter, suspended organic matter, harvest.

\section{Introduction}

Constructed wetlands are low-cost systems requiring a low input of energy, which makes them particularly appealing for the treatment of wastewater in small to medium-sized communities, and in developing countries (Brix, 1994a).

It has been widely demonstrated that vegetation is involved in almost every major function within constructed wetland treatment systems (Wrigley and Toerien, 1988; Brix, 1997; Greenway and Woolley, 2000). Specifically, vegetation in treatment wetlands acts as physical filters (Brix, 1994b); takes up nutrients and other constituents (Tanner, 1996; Greenway and Woolley, 1999; Liu et al., 2000); provides a substrate for microbiota and macroinvertebrates (Kadlec and Knight, 1996; Wetzel, 2000); contributes carbon and creates anaerobic zones for denitrification (Wrigley and Toerien, 1988; Mann and Wetzel, 1996); adds oxygen to sediment zones where mineralisation and nitrification occur (Reddy et al., 1989); and enhances denitrification by pulling nitrates from the water column into anaerobic zones within the sediments as the roots actively absorb water needed for transpiration (Martin et al., 2003).

Numerous studies have confirmed that water treatment is improved in vegetated systems compared with systems containing no plants (Wrigley and Toerien, 1988; Tanner and Sukias, 1995; Tanner, 1996; Matheson et al., 2002, etc.). However, most of these studies were done when the vegetation was new and actively growing, absorbing abundant amounts of nutrients, minerals, and water as the plants transpired and produced large amounts of biomass. As vegetation biomass increases, the role

\footnotetext{
To whom all correspondence should be addressed.

0034981 563100; fax: 0034981528050 ;

e-mail: uanantonio.alvarez@usc.es
}

of the vegetation in water treatment function shifts. When senescence begins, this mature vegetation dominates water treatment function by driving the carbon cycling and denitrification processes, while processes that are driven by active vegetation production are reduced. When vegetation biomass builds up to high levels, it can cause numerous problems, as documented in several studies (Gray et al., 1999; de Szalay and Resh, 2000; Pinney et al., 2000; Prior, 2000; Sartoris et al., 2000; Thullen et al., 2002). Some of the negative effects in constructed wetlands with high density of vegetation are:

- Dissolved oxygen (DO) concentrations are consistently lower than $1.0 \mathrm{mg} / \ell$, which can severely restrict nitrification and reduce the survival of larvivorous fish and invertebrate mosquito predators, as well as the microbes and macroinvertebrates that decompose senesced vegetation

- Dense vegetation can contribute significantly to internal nutrient loading as the plants decompose

- Both mature and standing dead plants shade algal and autotrophic microbial communities, thus reducing the nutrient-retention capacities (even if small and of short duration) of those communities. Shading also limits photolysis, which is necessary to kill pathogens, and to detoxify many organic contaminants.

In addition to managing vegetation expansion to avoid high density of vegetation, it is also important to manage plant litter accumulation and decomposition for the successful management and sustainability of constructed wastewater-treatment wetlands. In fact, eliminating excess litter is often necessary to restore positive functions important in constructed wetlands (Prior, 2000; Sartoris et al., 2000). In a particular constructed wetland, vegetation grows and emerges during spring and summer, but at the beginning of autumn, vegetation starts to decay and is decomposed during the rest of the year, contributing organic matter 
and nutrients to the system, and the effluent flow. For all these reasons, harvesting wetland vegetation in constructed wastewater-treatment wetlands has been a subject of intense debate (e.g. Wrigley and Toerien, 1988; Brix, 1994a; Wieder et al., 1994; Reed et al., 1994; Crites, 1994, Thullen et al., 2005).

The utility of harvesting for the operation of the process depends on many factors (e.g. weather, type of species, wastewater characteristics). A widely-held view is that harvest does not have a significant effect on nutrient removal (Brix, 1994a; Wieder et al., 1994), and some authors (e.g. Reed et al., 1994; Crites, 1994) do not recommend the technique because the amount of nutrients removed by harvesting is insignificant with respect to other processes involved (Brix, 1994b). Other disadvantages of harvesting are cost of maintenance, reduction of ecological value, effect of sediment re-suspension during harvest, and low buffer effect at low temperatures (Kadlec et al., 2000).

However, some authors recommend harvesting to improve hydraulic conductivity and mosquito control (Bendorichio et al., 2000), especially in warm areas where biomass production is high (Koottatep and Polpraset, 2000). Wrigley and Toerien (1988) indicated that removal of $\mathrm{N}$ and $\mathrm{P}$ from the reed bed studied (planted with Phragmites) by harvesting the aboveground biomass material ( $70 \mathrm{t} /$ ha per year), amounted to 750 and $76 \mathrm{~kg} / \mathrm{ha}$ per year, respectively. The performance of cattail (Typha spp.) systems may be improved by harvesting the plants at the end of the growing season, thus reducing additional BOD and TSS inputs from decaying biomass litter (Karathanasis et al., 2003).

On the other hand, an effective tool to manage and sustain healthy vegetation is the use of hummocks, which are shallow emergent plant beds within the wetland, positioned perpendicular to the water flow path and surrounded by water sufficiently deep to limit further emergent vegetation expansion (Thullen et al., 2005). The main functions of these hummocks are wetland vegetation management, and enhancing plan decomposition. Properly configured hummocks in a constructed wastewatertreatment wetland can therefore be used to maintain the proper balance of vegetation, create desirable macroinvertebrate habitat, accelerate plant decomposition, and increase hydraulic mixing and retention time (Thullen et al., 2005).

Macrophyte decomposition in wetlands increases gravel clogging in subsurface flow systems (SSF), and contributes to the sediment layer in free-water surface systems (FWS), leading to terrestrialisation of the wetland (Kirschner et al., 2001). In this work, we studied the effect of vegetation harvesting and its consequences for plant decomposition in winter and early spring, comparing a harvested with a non-harvested constructed wetland. The geo-climatic setting of the area in Spain, where the constructed wetland is situated, is the following: the location coordinates are $42^{\circ} 36^{\prime} \mathrm{N} 5^{\circ} 35^{\prime} \mathrm{W}$; mean annual precipitation is 400 to $500 \mathrm{~mm}$; potential evaporation is $0.1742 \mathrm{l} / \mathrm{h} \cdot \mathrm{m}^{2}$ (in summer, measured in situ during the experiment); altitude is $800 \mathrm{~m}$; and mean annual environmental temperature is $11^{\circ} \mathrm{C}\left(19^{\circ} \mathrm{C}\right.$ in summer and $5^{\circ} \mathrm{C}$ in winter).

\section{Materials and methods}

A horizontal surface-flow wetland with a total area of $88 \mathrm{~m}^{2}$, a substrate comprising $0.3 \mathrm{~m}$ of 6 to $8 \mathrm{~mm}$ diameter gravel, $0.4 \mathrm{~m}$ of water, and planted with Typha latifolia (3 $007.7 \mathrm{~g}$ $D W / \mathrm{m}^{2}$ ), was divided into two equal completely separate parts. Each wetland therefore had an area of $44 \mathrm{~m}^{2}$ (length: $11 \mathrm{~m}$, width: $4 \mathrm{~m}$ ). During the middle of the autumn, one part of the

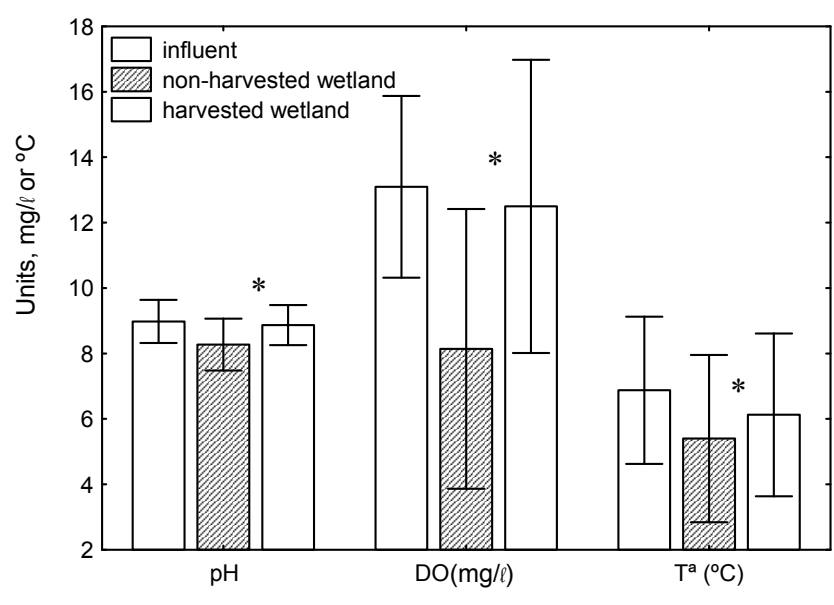

Figure 1

Values of $\mathrm{pH}$, dissolved oxygen (DO) and temperature in the influent, and non-harvested and harvested wetland effluents. *: Significant differences at $p<0.05$. Bars and whiskers indicate average values and standard deviation, respectively.

wetland was harvested and the other part was maintained with plants. The plants were harvested $2 \mathrm{~cm}$ above the water level to preserve the effect of stems on biofilm and hydraulics of the harvested wetland. The wetland was placed in the treatment plant of Cubillas de los Oteros, a small village of 150 inhabitants situated in León (North-west Spain). Overall, the facility consisted of a septic tank as pre-treatment, a stabilisation pond, a surface flow (the experimental wetland), and a subsurface flow wetland.

During winter (111 d of operation) and spring ( $30 \mathrm{~d}$ of operation), weekly samples of wetland influent, which is the same in both harvested and non-harvested wetlands, and of the effluents of each part of the wetland (harvested and non-harvested) were taken. Total and volatile suspended solids, (TSS, VSS), total and soluble chemical oxygen demand (TCOD, SCOD), and biological oxygen demand (BOD) were analysed following standard methods (Standard Methods, 1995); pH, temperature (T) and dissolved oxygen (DO) concentration were also measured in the wetlands. Student's t-test was used for statistical analyses.

The flow was $11.23 \mathrm{~m}^{3} / \mathrm{d}$ until Day 79 of operation, and from Day 79 until the end of the operation, the flow was $8.64 \mathrm{~m}^{3} / \mathrm{d}$. The flow was controlled in this manner to maintain the organic load rate at below $12 \mathrm{gBOD} / \mathrm{m}^{2} \cdot \mathrm{d}$. The average HRT (hydraulic retention time) applied to each part of the wetland was $44.4 \mathrm{~h}$. The organic load was maintained at about $11.4 \mathrm{~g} / \mathrm{m}^{2} \cdot \mathrm{d}$.

\section{Results and discussion}

\section{Physico-chemical parameters}

Influent $\mathrm{pH}$ was about 9.0 units, a typical value for a facultative lagoon effluent (Henze et al., 2000) (Fig. 1). Effluent $\mathrm{pH}$ was significantly different (Student's t-test, $\mathrm{p}<0.05)$ between harvested and non-harvested wetlands ( 8.9 and 8.3 units, respectively). The average temperatures were $6.9,5.4$ and $6.1^{\circ} \mathrm{C}$ in influent, non-harvested wetland and harvested wetland, respectively, these differences also being statistically significant. Main differences with respect to DO concentration were observed between influent and non-harvested wetland (13.1, 8.1 and $12.5 \mathrm{mg} / \ell$ in influent, non-harvested and harvested wetland, respectively).

Vegetation clearly influenced the physico-chemical environment of the wetland. Presumably, higher organic matter in the non-harvested wetland would be responsible for a higher oxida- 
Figure 2

Organic matter of influent (circles), non-harvested (squares) and harvested (triangles) effluent during the study period.
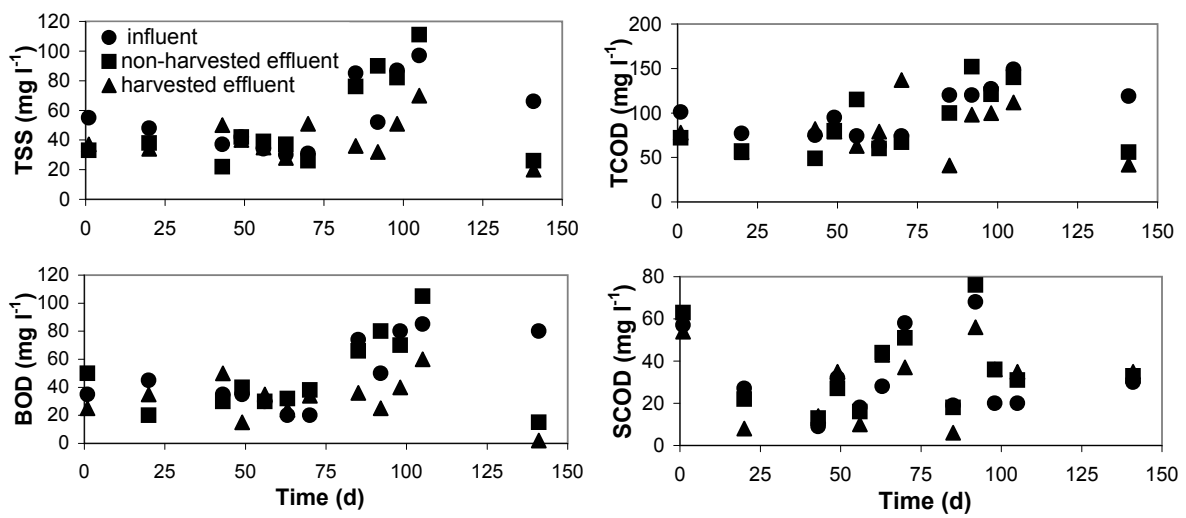

tion activity, causing lower $\mathrm{pH}$ and higher oxygen utilisation in the vegetated part. Vegetation also maintained a higher thermal inertia in the vegetated part, compared with the harvested part. Plants helped to maintain the lower temperatures reached during the night (frequently below $0^{\circ} \mathrm{C}$ during winter), which resulted in lower values at the sampling time (noon) in the vegetated part in comparison with the harvested part. Absence of plants allowed for higher water temperatures at noon and higher light incidence in the harvested part in comparison with the vegetated part, often frozen for several days in winter. This aspect confirms the important thermal inertia of the vegetation (Brix, 1994a), but in the opposite way.

\section{Organic matter}

Values of TSS, TCOD, SCOD and BOD are presented in Fig. 2. Two different operational periods were observed: from Day 1 to 70 (winter period) and from Day 70 to 141 (late winter and early spring period), particularly evident in the TSS and BOD plots.. Average values for each period are presented in Table 1. Differences between the effluents with and without vegetation were not significant in the first period (Day 1 to 70) (Student's t-test, $p>0.05$ ) Higher values of the effluent characteristics were observed for the non-harvested wetland in the second period of the study (Day 70 to 141). The analysis of data showed that TSS, TCOD and BOD values were statistically different and that a higher removal of suspension and biodegradable organic matter was observed in the harvested part (Table 2). Effluent TSS and BOD were removed to a greater extent in the harvested than in the non-harvested wetland $(45.4 \%$, from 77 to $42 \mathrm{mg} / \ell$; and $50.7 \%$, from 67 to $33 \mathrm{mg} / \ell$, for TSS and BOD, respectively).

The performance of the systems planted with cattails may be improved by harvesting the plants at the end of the growing season, thus reducing additional BOD and TSS inputs from decaying biomass litter. Similar to our findings, Karathanasis et al. (2003) observed that the decline in BOD removal efficiency in cattail systems occurred mainly in the spring, probably due to the large biomass production during winter. This caused an increase in effluent BOD in spring, when increasing temperatures contribute to more rapid decay of plant material.

From laboratory experiments on Typha spp. decomposition at different HRTs (from 1.6 to 7.4 d), Pinney et al. (2000) showed that at higher HRTs, the Typha released a large amount of organic carbon. However, of the carbon released, 5 to $8 \%$ was transformed to dissolved organic carbon; 45 to $60 \%$ accumulated as biomass, and 35 to $60 \%$ was used in bacterial growth or was decomposed by fermentation to $\mathrm{CO}_{2}$ and $\mathrm{CH}_{4}$. Despite the fact that dissolved organic carbon released by the plants is low, the large amount of vegetation biomass produced could have an important effect on the BOD of the final effluent.

Another aspect to take into account in a wetland is the role of the plankton community within the system. Luyiga et al. (2003) observed that the plankton community increased dissolved oxygen levels and $\mathrm{pH}$, improving $\mathrm{BOD}$ and $\mathrm{NH}_{4}$ removal. They also observed that BOD removal was mainly carried out in the proximal portion of the wetland (first $8^{\text {th }}$ ), whereas an increase in BOD as a consequence of plant decay and plankton activity was observed in the distal part of the wetland. In addition, Baptista et al. (2003), studying two laboratory-scale wetlands, with and without vegetation, observed that carbon removal was higher in the unplanted part (63\% vs. 51\%). In our study, Table 2 shows that BOD removal in the harvested and non-harvested system was $55.8 \%$ and $8.9 \%$, respectively, during late winter/ early spring (Days 70 to 141 ).

TABLE 1

Average values and statistical differences among the effluents in the studied conditions (values in $\mathrm{mg} / \ell$ ). ${ }^{*} p<0.05,{ }^{* *} p<0.01$.

\begin{tabular}{|l|c|c|c|c|c|c|c|c|c|c|c|c|}
\hline & \multicolumn{4}{|c|}{ Influent } & \multicolumn{4}{c|}{ Non-harvested effluent } & \multicolumn{4}{c|}{ Harvested effluent } \\
\hline & TSS & TCOD & SCOD & BOD & TSS & TCOD & SCOD & BOD & TSS & TCOD & SCOD & BOD \\
\hline Day 1-70 & 40 & 80 & 33 & 31 & $\mathbf{3 4}$ & $\mathbf{7 1}$ & $\mathbf{3 4}$ & $\mathbf{3 4}$ & $\mathbf{3 9}$ & $\mathbf{8 2}$ & $\mathbf{2 9}$ & $\mathbf{3 1}$ \\
\hline Day 70-141 & 77 & 127 & 31 & 74 & $\mathbf{7 7}^{*}$ & $\mathbf{1 1 4}^{*}$ & $\mathbf{3 9}$ & $\mathbf{6 7 * *}$ & $\mathbf{4 2}^{*}$ & $\mathbf{7 9}^{*}$ & $\mathbf{3 4}$ & $\mathbf{3 3} * *$ \\
\hline
\end{tabular}

TABLE 2

Average removal efficiencies (\%) of organic matter and statistical differences in both wetlands: harvested and non-harvested. ${ }^{*} p<0.05$.

\begin{tabular}{|l|c|c|c|c|c|c|c|c|}
\hline & \multicolumn{4}{|c|}{ Non-harvested (\%) } & \multicolumn{5}{c|}{ Harvested (\%) } \\
\hline & TSS & TCOD & SCOD & BOD & TSS & TCOD & SCOD & BOD \\
\hline Day 1-70 & 14.4 & 10.6 & -3.1 & -9.1 & 0.7 & -2.7 & 12.2 & 0.9 \\
\hline Day 70-141 & $0.5^{*}$ & $10.4^{*}$ & -23.6 & $8.9^{*}$ & $46.0^{*}$ & $38.1^{*}$ & -7.0 & $55.8^{*}$ \\
\hline
\end{tabular}




\section{Organic matter production from Typha latifolia}

The organic matter released from the wetland vegetation during the second part of the experiment, (final part of winter and initial part of spring, operational days between 70 and 141), can be calculated. In this period, the BOD difference between harvested and non-harvested wetland was $34 \mathrm{mg} / \ell$ (67 minus 33, Table 1). Taking into account that each wetland has an area of $44 \mathrm{~m}^{2}$, a water volume of $16.5 \mathrm{~m}^{3}$ and a vegetation density of $3007.7 \pm$ 1120.2 gDWTypha $/ \mathrm{m}^{2}$, BOD released per dry gram of Typha was $4.24 \mathrm{mgBOD} / \mathrm{g}$ Typha.

The BOD background concentration produced in the biological process can be calculated according to Kadlec and Knight (1996) using the following equation:

$$
C_{B O D}^{*}=3.5+0.053 \cdot C_{i}
$$

where:

$$
\begin{aligned}
& C^{*} \text { BOD is BOD background concentration } \\
& C_{i} \text { is the influent BOD concentration }
\end{aligned}
$$

The equation $\left(\mathrm{R}^{2}=0.67\right)$ is applied to surface-flow and subsurface-flow wetlands with $C_{i}$ lower than $200 \mathrm{mg} / \ell$. With an influent BOD of $74 \mathrm{mg} / \ell$ (Table 1 ), $\mathrm{C}^{*}{ }_{\text {воD }}$ is of $7.4 \mathrm{mg} / \ell$. Comparison of this value with Table 1 reflects that BOD background concentration in our system $(34 \mathrm{mg} / \ell)$ is 4.6 times the background concentration estimated according to Kadlec and Knight (1996). This means that autochthonous organic matter which originated as a result of vegetation decomposition is much higher than the expected background concentration according to Kadlec and Knight (1996).

With respect to TSS produced per dry gram of Typha, and taking into account data from Table 1 ( 77 minus $42=35 \mathrm{mg} / \ell$ of difference between each wetland studied), wetland area, water volume and Typha density of the wetland, a value of 4.36 mgTSS/gTypha is obtained. TSS background concentration can be also estimated according to Kadlec and Knight (1996), with the following equation:

$$
C_{T S S}^{*}=5.1+0.016 \cdot C_{i}
$$

where:

$\mathrm{C}_{\text {TSS }}^{*}$ is TSS background concentration

$\mathrm{C}_{\mathrm{i}}$ is the influent TSS concentration

The equation $\left(\mathrm{R}^{2}=0.23\right)$ is applied to surface-flow wetlands with $\mathrm{C}_{\mathrm{i}}$ lower than $807 \mathrm{mg} / \ell$. In this case, TSS concentration released from the vegetation was 2 times the background concentration calculated according to Kadlec and Knight (1996). In this case, organic matter supplied by vegetation decomposition measured as TSS is lower than $\mathrm{BOD}_{5}$; this supports the evidence that the autochthonous organic matter is mainly formed by soluble biodegradable matter.

Kadlec and Knight (1996) found Typha spp. litter decomposition rates in wetland ecosystems in the range from 0.0013 to $0.0031 \cdot \mathrm{d}^{-1}$. Álvarez and Bécares (2006) found a mean summer value of $\mathrm{k}_{\mathrm{d}}$ of $0.0043 \cdot \mathrm{d}^{-1}$, similar to the mean estimates found in other studies (e.g. Nelson et al., 1990; Vymazal, 1995). These results suggest that Typha latifolia is one of toughest and most resistant emergent macrophytes in wetlands. The low Typha decay rate means detritus will remain in the system for a long time and could clog or deepen sediment layers in the wetland. Nevertheless, estimation of terrestrialisation rates in surfaceflow wetlands (Álvarez and Bécares, 2006) suggests that sediment accumulation is much lower than the life-span of the wastewater treatment system.

\section{Conclusions}

Our results support the claim of Soto et al. (1999) that, when treating diluted wastewater, vegetation has a significant effect on the efficiency of the system, but also contributes significantly to the supply of autochthonous organic matter to the system. Our study demonstrates that vegetation harvest within created wastewater treatment wetlands has a significant effect on $\mathrm{pH}$, dissolved oxygen, and temperature, as the absence of vegetation will improve algae photosynthesis and decrease thermal inertia. Furthermore, the absence of vegetation decomposition allows a reduction in effluent TSS and BOD concentration by $45.4 \%$ and $50.7 \%$, respectively, relative to a non-harvested wetland, for the late winter/early spring period. The data show that harvest is a recommended operation and management strategy in the climatic setting described.

\section{Acknowledgments}

Our thanks to Roberto Reinoso and Linda Torres for their help during sampling at the wastewater treatment plant of Cubillas de los Oteros (León) and to Antonio Ribón for his help in laboratory and field work. Part of this work was funded by the Instituto Tecnológico Agrario (ITA) of the Castilla and León Government (LE-02. 2005). JA Alvarez was funded by a post-doctoral grant from the Xunta de Galicia and the Spanish Education Ministry.

\section{References}

ÁLVAREZ JA and BÉCARES E (2006) Seasonal decomposition of Typha latifolia in a free-water surface constructed wetland. Ecol. Eng. 28 99-105.

BAPTISTA JDC, DONNELLY T, RAYNE D and DAVENPORT RJ (2003) Microbial mechanisms of carbon removal subsurface flow wetlands. Water Sci. Technol. 48 (5) 127-134.

BENDORICHIO G, CIN LD and PERSSON J (2000) Guidelines for free wastewater wetland design. Ecol. Sys. Bd. 8 51-91.

BRIX H (1994a) Use of constructed wetlands in water pollution control: Historical development, present status and future perspectives. Water Sci. Technol. 30 (8) 209-223.

BRIX H (1994b) Functions of macrophytes in constructed wetlands. Water Sci. Technol. 29 (4) 71-78.

BRIX H (1997) Do macrophytes play a role in constructed treatment wetlands? Water Sci. Technol. 35 (5) 11-17.

DE SZALAY FA, BATZER DP, SCHLOSSBERG EB and RESH VH (1995) A comparison of small and large scale experiments examining the effects of wetland management practices on mosquito densities. Proc. Mosq. Vector Control Assoc. Calif. 63 86-90.

CRITES RW (1994) Design criteria and practice for constructed wetlands. In: Proc. of the Int. Conf. Wetland Systems in Water Pollution Control. 23-25 November 1992, Sydney, Australia.

GRAY MJ, KAMINSKI RM, WEERAKKODY G, LEOPOLD BD and JENSEN KC (1999) Aquatic invertebrate and plant responses following mechanical manipulations of moist-soil habitat. Wildlife Soc. Bull. 27 770-779.

GREENWAY M and WOOLLEY A (1999) Constructed wetlands in Queensland: performance efficiency and nutrient bioaccumulation. Ecol. Eng. 12 39-55.

GREENWAY M and WOOLLEY A (2000) Changes in plant biomass and nutrient removal over 3 years in a constructed free water surface flow wetland in Cairns, Australia. In: Proc. of Seventh Int. Conf. on Wetland Systems for Water Pollution Control 2. Lake Buena Vista, FL (USA) 707-718.

HENZE M, HARREMOËS P, LA COUR JANSEN JE and ARVIN E (2000) Wastewater Treatment: Biological and Chemical Processes 
( $3^{\mathrm{a}}$ edn.) Springer Verlag, Berlín, Germany.

KADLEC RH and KNIGHT RL (1996) Treatment Wetlands. Lewis Publishers. Boca Raton, FL, USA.

KADLEC RH, KNIGHT RL, VYMAZAL J, BRIX H, COOPER P and HABERL R (2000) Constructed Wetlands for Pollution Control. Scientific and Technical Report 8; IWA Publishing, London.

KARATHANASIS AD, POTTER CL and COYNE MS (2003) Vegetation effects on fecal bacteria, BOD, and suspended solid removal in constructed wetlands treating domestic wastewater. Ecol. Eng. 20 157-169.

KIRSCHNER AKT, RIEGL B and VELIMIROV B (2001) Degradation of emergent and submerged macrophytes in an oxbow lake of an embanked backwater system: Implications for the terrestrialization process. Int. Rev. Hydrobiol. 86 555-571.

KOOTTATEP T and POLPRASET DC (2000 Role of plant uptake on nitrogen removal in constructed wetlands located in the tropics. Water Sci. Technol. 36 (12) 1-8.

LIU J, QIU C, XIAO B and CHENG Z (2000) The role of plants in channel-dyke and field irrigation systems for domestic wastewater treatment in an integrated eco-engineering system. Ecol. Eng. 16 235-241.

LUYIGA S and KIWANUKA S (2003) Plankton composition, distribution and significance in a tropical integrated constructed treatment wetland in Uganda. Water Sci. Technol. 48 (5) 241-248.

MANN CJ and WETZEL RG (1996) Loading and utilization of dissolved organic carbon from emergent macrophytes. Aquat. Bot. $\mathbf{5 3}$ 61-72.

MARTIN J, HOFHERR E and QUIGLEY MF (2003) Effects of Typha latifolia transpiration and harvesting on nitrate concentrations in surface water of wetland microcosms. Wetlands 23 (4) 835-844.

MATHESON FE, NGUYEN ML, COOPER AB, BURT TP and BULL DC (2002) Fate of 15N-nitrate in unplanted, planted and harvested riparian wetland soil microcosms. Ecol. Eng. 19 249-264.

NELSON JW, KADLEC JA and MURKIN HR (1990) Seasonal comparisons of weight loss of two types of Typha glauca Godr. leaf litter. Aquat. Bot. 37 299-314.

PINNEY ML, WESTERHOFF PK and BAKER L (2000) Transformations in dissolved organic carbon through constructed wetlands. Water Res. 34 1897-1911.

PRIOR B (2000) Sweetwater wetlands mosquito control update. Mosq. Connect. 5 4-5.
REDDY KR, D'ANGELO EM and DEBUSK TA (1989) Oxygen transport through aquatic macrophytes: the role in wastewater treatment. J. Environ. Qual. 19 261-267.

REED SR, CRITES RW and MIDDLEBROOKS JE (1995) Natural Systems for Waste Management and Treatment. McGraw-Hill (ed.) New York, USA.

SARTORIS JJ, THULLEN JS, BARBER LB and SALAS DE (2000) Investigation of nitrogen transformations in a southern California constructed wastewater treatment wetland. Ecol. Eng. 14 49-65.

SOTO F, GARCÍA M, DE LUÍS E and BÉCARES E (1999) Role of Scirpus lacustris in bacterial removal from wastewater. Water Sci. Technol. 40 (3) 241-247.

STANDARD METHODS (1995) Standard Methods for Water and Wastewater Examination (19 th $^{\text {edn. }}$. Am. Public Health Assoc. (APHA), Washington D.C.

TANNER CC (1996) Plants for constructed wetland treatment systems - a comparison of the growth and nutrient uptake of eight emergent species. Ecol. Eng. 7 59-83.

TANNER CC and SUKIAS JP (1995). Accumulation of organic solids in gravel-bed constructed wetlands. Water Sci. Technol. 32 (3) 229239.

THULLEN JS, SARTORIS JJ and WALTON WE (2002) Effects of vegetation management in constructed wetland treatment cells on water quality and mosquito production. Ecol. Eng. 18 441-457.

THULLEN JS, SARTORIS JJ and NELSON SM (2005) Managing vegetation in surface-flow wastewater-treatment wetlands for optimal treatment performance. Ecol. Eng. 25 583-593.

WETZEL RG (2000) Fundamental processes within natural and constructed wetland ecosystems: short-term vs. long-term objectives. In: Proc. of $7^{\text {th }}$ Int. Conf. on Wetland Systems for Water Pollution Control 2. Lake Buena Vista, FL (USA). 3-11.

WIEDER RK, TCHOBANOGLOUS G and TUTTLE RW (1994) Preliminary considerations regarding constructed wetlands for wastewater treatment. In: Hammer DA (ed.) Constructed Wetlands for Wastewater Treatment. Lewis Publ. Chelsea, London, UK.

WRIGLEY TJ and TOERIEN DF (1988) The ability of an artificially established wetland system to upgrade oxidation pond effluent to meet water quality criteria. Water SA 14 (4) 171-178.

VYMAZAL J (1995) Algae and Element Cycling in Wetlands. Lewis Publishers, Boca Raton, FL, USA. 
Available on website http://www.wrc.org.za ISSN 0378-4738 = Water SA Vol. 34 No. 5 October 2008 ISSN 1816-7950 = Water SA (on-line) 